\title{
PERFORMANCE CLEANING UNIT FOR CLOVER SEEDS AFFECTING SOME PHYSICAL AND MECHANICAL PROPERTIES
}

\author{
R. A. WERBY
}

\section{ABSTRACT}

The primary objective of this investigation was to provide database about the physical properties (length, width, mass of 1000 -seeds, volume, percent of sphericity, geometric diameter, arithmetic diameter, transverse surface area, flat surface area, true density and bulk density ) and mechanical properties ( friction angle, angle of repose, hardness, and terminal velocity) of clover seeds. Also, to study some parameters affecting cleaning unit such as diameter of holes, air speed, sieve tilt angle, sieve oscillation with feed rate of $500 \mathrm{~kg} / \mathrm{h}$, and moisture content of $10.5 \%$. Three different varieties of clover seeds: AL-Mesqawi, ALKhadrawi and Al-Seadi which are considered as the most important clover seeds in Egypt. The results indicated that :Length, and width, for AL-Mesqawi, AL-Khadrawi and Al-Seadi were 2.40, and 2.10; 2.45and $2.12 ; 3.00$ and $2.10 \mathrm{~mm}$ respectively. percent of sphericity and Volume for AL-Mesqawi, AL-Khadrawi and Al-Seadi were 87, 86 and $70 \%$; $4.55,4.65$, and $5.36 \mathrm{~mm}^{3}$ respectively.

Friction angle with three sheets from stainless steel, metal and wood was 24, 31and 36 degree; 24, 31, and 37 degree;25, 32 and 38 degree for AL-Mesqawi, AL-Khadrawi and Al-Seadi respectively. Terminal velocities for AL-Mesqawi, AL-Khadrawi and Al-Seadi were ,15 , 15 and $16 \mathrm{~m} / \mathrm{s}$ respectively.

From the study, the principals parametere of sieve unit, the diameters of round sieve hole were , 3.0, 3.0 and $3.5 \mathrm{~mm}$ for AL-Mesqawi, ALKhadrawi and Al-Seadi respectively. The main results of this study can be summarized as follows:

- The cell area depends on the physical properties of seeds clover and its shape depends on the percent of sphericity of seeds. The separation can be achieved on the basis of length using a screen aperture of $4 \mathrm{~mm}$

Lect., Ag. Eng. Dept., Fac.of Ag., Al-Azhar Univ. 
diameter, and percentage of sphericity of approximately $85 \%$ on length for circular hole.

- Terminal velocity to suspend clover seeds ( variety AL-Mesqawi, ALKhadrawi and Al-Seadi) was $16 \mathrm{~m} / \mathrm{s}$.

- The results showed that cell shape, sieve tilt angle, sieve oscillation and air speed were the main factors that affect purity and total losses in cleaning.

- The results showed that cell shape, sieve tilt angle, sieve oscillation and air speed were the main factors that affect purity and total losses in cleaning. The purity increased by increasing air speed, sieve tilt angle and sieve oscillation. Total losses increased by increased air speed, sieve tilt angle and oscillation.

-The optimum performance was at air speed of $6 \mathrm{~m} / \mathrm{s}$, moisture content of $10.5 \%$, sieve oscillation of $250 \mathrm{rpm}$, sieve tilt angle of $3^{5}$, round shaped sieve $4 \mathrm{~mm}$ diameter, and feed rate of $500 \mathrm{~kg} / \mathrm{h}$. purity at these conditions was $99 \%$ and total losses $1 \%$.

\section{INTRODUCTION}

lover seed considered among the most important plants in Egypt.

To increase seed production with good quality, scientists are studying physical and mechanical properties seed from an engineering standpoint. These properties can be exploited as a guide in designing methods for such seed production as planting, and testing particular cleaning machines.

Mohsenin (1986) reported that the physical properties of any material such as shape, volume, and surface area are important in many problems associated with design or development of specific machine or analyzing the behavior of the product in handling or grading of the material. Islam et al.(1980) mentioned that a seed cleaner to clean various seeds and grain employs various methods of separation, according to width, length, thickness and weight of grain. El-Raie (198 $\vee$ ) studied the shape and size of three varieties of corn at the storage moisture content in terms of length, width, thickness, volume, geometric diameter, arithmetic diameter, percent of spherically, area of flat surface and area of the transverse 
surface of the individual seeds. Arora (1991) concluded that the engineering properties such as size, diameter, volume, bulk density, particle density, porosity, terminal velocity, drag coefficient and resistance coefficient. Physical properties were found to be related to Mc., physical properties were linearly dependent upon Mc.The aerodynamic properties (terminal velocity, drag-coeff. and resistance coeff.) also increased with an increase in Mc.. Soliman (1994) studied the effect of moisture content on angle of repose of paddy rice. He concluded that the dynamic angle of repose, is one of the physical properties needed for the design of material handling systems and storage facilities for rice and rice products. Nimkar and Hattopaddhyay (2001) examined some physical properties of green grain as a function of moisture content in the range of 8.39 to $33.40 \%(\mathrm{db})$. The average length, width, thickness and thousand grain mass were $4.21 \mathrm{~mm}, 3.17 \mathrm{~mm}, 3.08 \mathrm{~mm}$ and $28.19 \mathrm{~g}$ at moisture content of $8.39 \%(\mathrm{db})$. The geometric mean diameter increased from 3.45 to $3.77 \mathrm{~mm}$, whereas sphericity decreased from 0.84 to 0.81 . Studies on rewetted grains showed that the bulk and true densities decreased from 807 to $708 \mathrm{~kg} / \mathrm{m}^{3}$ and 1363 to $1292 \mathrm{~kg} / \mathrm{m}^{3}$, respectively, whereas the corresponding bulk porosity increased from 10.1 to $12.1 \mathrm{~m} / \mathrm{s}^{1}$. The static coefficient of friction varied from 0.344 to 0.625 over different material surfaces, while angle of repose varied from 26.6 to 31 Within the studied moisture range. Gomea (1992) studied some physical properties of wheat grains during cleaning and separating operation. Harmond et al. (1965) reported that, terminal velocity represents the maximum velocity of a seed will attain in free fall through still air. If conditions are reversed so that the seed remains suspended in a rising air stream. The air must be moving at a speed equal to the terminal velocity of the seed. They mentioned that air separations could be employed in seed cleaning to separate inter the material, weed and other contaminants from crop seeds provided these components possess different terminal velocities.

The objective of this work was to study some physical and mechanical properties of some varieties of clover cultivated in Egypt. These properties may be utilized effectively in the design and development of precision planting, handling, cleaning, machines. 


\section{The aim of this study is represented as the following points.}

- Study the physical and mechanical properties of three Egyptian varieties of clover seeds (AL-Mesqawi, AL-Khadrawi and Al- Seadi,),this properties provides data base, consequently it can be used as a guide in seed production.

- To obtain the engineering parameters of the suitable separation device from physical and mechanical properties of the threshed materials.

- Determine the terminal velocity values to suspended clover seeds and their impurities.

\section{MATERIALS AND METHODS}

This work was carried out in 2009 season, in order to determine some physical and mechanical properties of seeds of three clover varieties commonly cultivated in Egypt. These varieties are: AL-Mesqawi, ALKhadrawi and Al-Seadi, and also to study some parameters affecting cleaning unit such as diameter of holes, air speed, sieve tilt angle, and sieve oscillation. The physical and mechanical properties studied may help in choose altering or design of a suitable machine for cultivating, handling, cleaning of clover seeds.

\section{- Machine specifications and description:}

In investigation, the cleaner of seed used for clover winnowing, was constructed and tested. The machine followed the design of Khan et al., 197. The portable seed cleaner was developed to fill the need for a faster and more efficient method of seed cleaning. The machine is easy to operate and convenient to service and maintain. The cleaning machine consists of a frame, a seed hopper, an oscillating dual-screen assembly, a centrifugal blower and an electric motor as shown in fig. 1 . General specifications of machine are : overall length $1428 \mathrm{~mm}$, overall width 570 $\mathrm{mm}$, overall height $1210 \mathrm{~mm}$, power of $0.3 \mathrm{hp}$, labor requirement $1 \mathrm{man}$, easy operation; minimum adjustments, reduced repairs and maintenance problems. Multi crop capability, includes two screens with interchangeable top screen. Simple design, includes integral shaft for horizontal oscillating screen drive and fan. Construction includes $1 \mathrm{~mm}$ sheet metal and $30 \times 30 \times 3 \mathrm{~mm}$. angle iron. 
Frame: Made of angle steel sections 30 x 30 x $3 \mathrm{~mm}$.

Hopper: Made of steel sheet metal of $1 \mathrm{~mm}$ thickness and angle iron steel section $30 \times 30 \times 3 \mathrm{~mm}$.

Sieves: Made of steel sheet metal of $1.5 \mathrm{~mm}$ thickness. They consist of upper and lower sieves and hang on four links ( 2 fixed rods in the front and 2 adjustable in the rear to alter the sieve tilt angle). The upper sieve has two sheets; one solid under the hopper gate and the other perforated 3 $\mathrm{mm}$ hole diameter for separating chaff and straw from seed. The lower sieve is mounted $150 \mathrm{~mm}$ below and parallel to the upper screen. The lower screen has $1 \mathrm{~mm}$ diameter holes to remove fine impurities and dust. The proper mesh-size of the sieves was determined from physical properties of seed.

Blower; The blower is made of metal sheet of $1 \mathrm{~mm}$ thickness . The blower fan assembly consists of six bladed radial fan, driver from electric motor with V-shape pelt bully. The fan discharges air blast through the sieve perforations.

\section{-Measuring instrumentation:}

Digital dial caliper; with accuracy of $0.05 \mathrm{~mm}$ was used dimensions (length, width and thickness) of clover seeds were determined considering the three axes $\mathrm{x}, \mathrm{y}$ and $\mathrm{z}$.

Electrical balance: An electronic balance was used for weighing samples before and after cleaning. Its scale ranged from 0 to $5 \mathrm{~kg}$ max., with accuracy of $0.2 \mathrm{~g}$.

Electrical oven: with forced hot air circulation of maximum temperature of $300 \mathrm{c}^{0}$.

Rigidity force: A digital force gauge with accuracy of $0.2 \%$ was used for measuring the rigidity force. It has a maximum reading of $2200 \mathrm{~g}$, so, construction was used for amplifying force reading.

Anemometer instrument, An anemometer instrument (SATAKE CO., Japan) was used for measuring the air speed, temperature, and pressure. It is ranged from 0 to $50 \mathrm{~m} / \mathrm{s}$. The measurement theory depends on the declination of the sensor inside the instrument. The movement of air pushes 

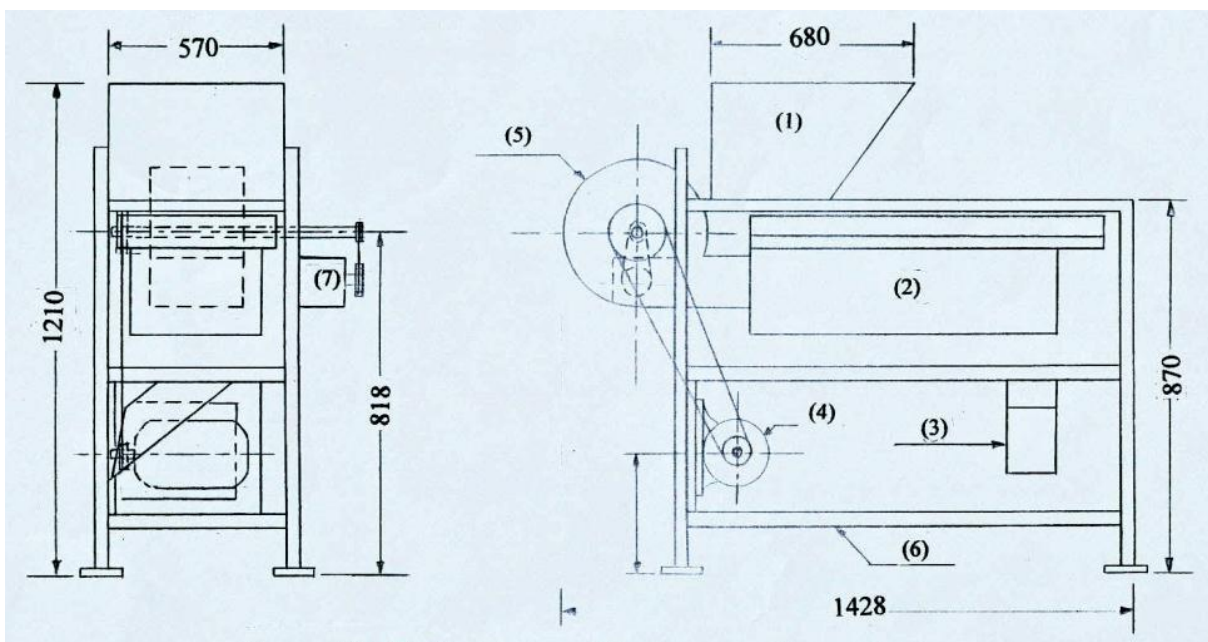

Fig. (1): Sketch view of the cleaner machine. Dim. in $\mathrm{mm}$.

$$
\begin{aligned}
& \begin{array}{c}
\text { 1-Hopper 2-Screen 3-Spout 4-motor } \\
\text { 5-Fan }
\end{array} \\
& 5 \text {-Fan 6-Main farm 7-Eccentric }
\end{aligned}
$$

Fig. (1): Sketch view of the cleaner machine. Dim. in $\mathrm{mm}$.

$$
\begin{aligned}
& \text { 1- Hopper 2-Screen 3-Spout 4-motor } \\
& 5 \text { - Fan 6-Main farm } 7 \text { - Eccentric }
\end{aligned}
$$

the sensor then voltage indicates the variation of the air speed ( source of power is battery).

\section{Digital instrument for measuring coefficient of friction.}

It was used to measure the friction angle on stainless steel, metal, and wood sheet surface with dimensions 14 x $30 \mathrm{~cm}$.

\section{Experimental procedure:}

\section{Moisture contents:}

The moisture contents was determined for clover seeds using the oven methods according to ASAE standard ISBN 0-929355-50.4 Library of congress. (1994).

\section{Seed dimensions:}

The sample of seeds about 300 seeds was taken randomly to carrying out the required measurements.

The main dimensions length "L", and width "W" were measured using a digital vernier calper and the mean value was calculated for each sample. The following equations ( used by El-Raie et al (1996) for some agriculture products) were used to calculated of geometric diameter $\left(D_{g}\right)$ 
PROCESS ENGINEERING

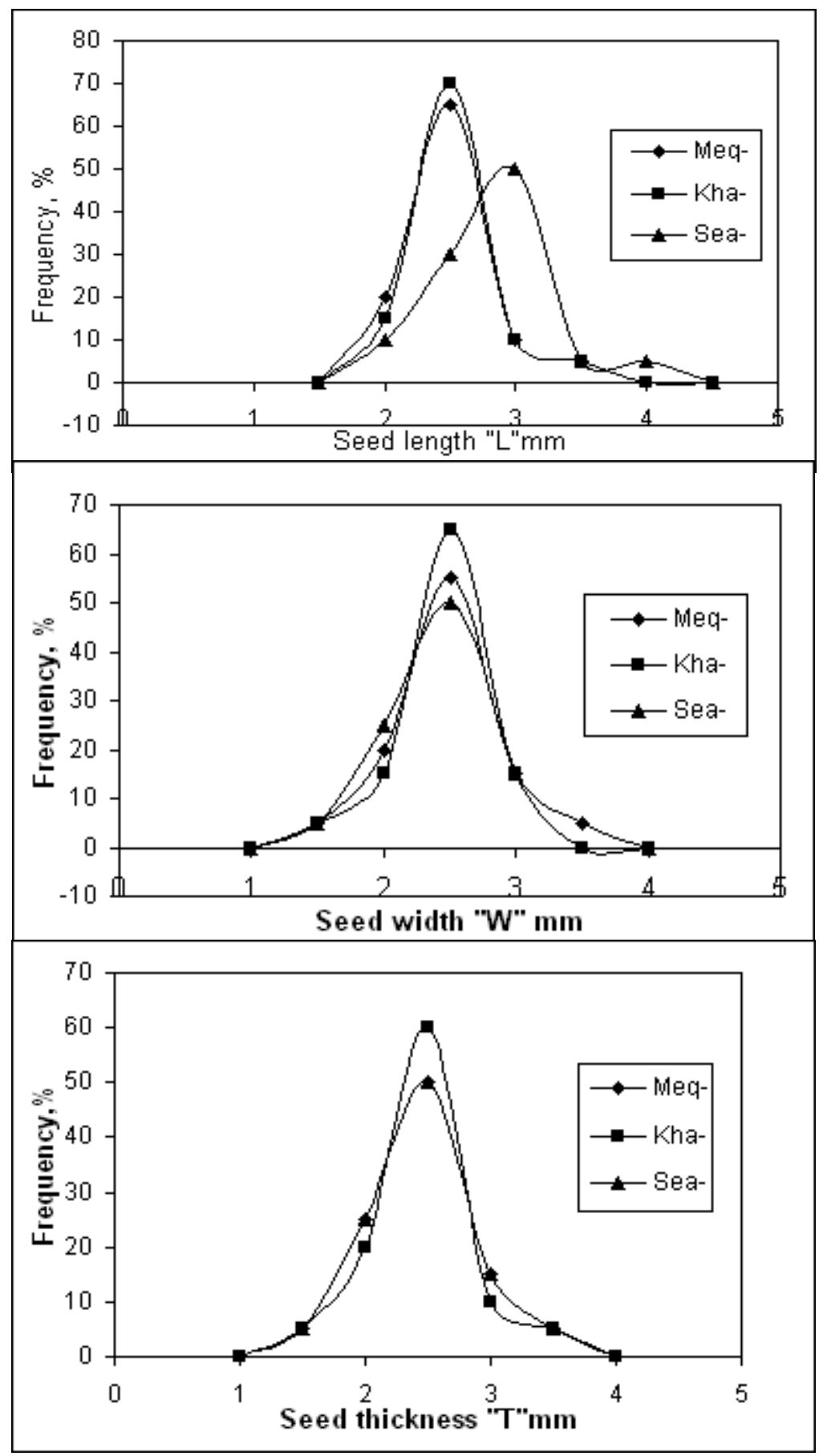

Fig.(2) Frequency distribution for length 'L', width "W" and thickness "T" of clover seeds (variety AL-Meqawei, AL-Khadrawi and AL-Swadi) 
arithmetic diameter $\left(D_{a}\right)$, volume $(V)$, area of flat surface $\left(A_{f}\right)$, area of transverse surface $\left(A_{t}\right)$ of an individual grain in millimeters, mass of 1000-kernels g, percent of sphericity $\%$, and bulk density $\mathrm{kg} / \mathrm{m}^{3}$.

$$
\begin{gathered}
\mathrm{V}=(\pi / 6)\left(\mathrm{L}^{*} \mathrm{~W}^{*} \mathrm{~T}\right) \mathrm{mm}^{3}---- \\
\mathrm{S}=100^{*}\left(\mathrm{~L}^{*} \mathrm{~W}^{*} \mathrm{~T}^{*}\right)^{1 / 3} / \mathrm{L} \% \\
\mathrm{D}_{\mathrm{g}}=\left(\mathrm{L}^{*} \mathrm{~W}^{*} \mathrm{~T}^{*}\right)^{1 / 3} \mathrm{~mm}------ \\
\mathrm{Da}=\left(\mathrm{L}^{*} \mathrm{~W}^{*} \mathrm{~T}^{*}\right)^{1 / 3} \mathrm{~mm}^{-------} \\
\mathrm{A}_{\mathrm{t}}=(\pi / 4)\left(\mathrm{T}^{*} \mathrm{~W}^{*}\right) \mathrm{mm}^{2}------- \\
\mathrm{A}_{\mathrm{f}}=(\pi / 4)\left(\mathrm{L}^{*} \mathrm{~W}^{*}\right) \mathrm{mm}^{2}-----
\end{gathered}
$$

Where:

$\mathrm{L}=$ length, $\mathrm{mm} \quad \mathrm{w}=$ width, $\mathrm{mm} \quad \mathrm{T}=$ thickness, $\mathrm{mm}$

$\mathrm{V}=$ volume, $\mathrm{mm}^{3} \quad \mathrm{~S}=$ percentage of sphericity, $\%$

$\mathrm{D}_{\mathrm{g}}=$ geometric diameter, $\mathrm{mm} \quad \mathrm{D}_{\mathrm{a}}=$ arithmetic diameter, $\mathrm{mm}$

$\mathrm{A}_{\mathrm{t}}=$ transverse surface area, $\mathrm{mm}^{2} \quad \mathrm{~A}_{\mathrm{f}}=$ flat surface area, $\mathrm{mm}^{2}$

\section{Volume:}

The volume of individual seed" $\mathrm{V}_{\mathrm{a}}$ "was measured as the increase volume in $5 \mathrm{ml}$ sodium nitrate.

\section{Friction and Repose angle of seeds:}

Friction " $\theta$ " and Repose " $\omega$ "angles were determined. The friction angle was determined between the seeds and a steel surface according to Mohsenin (1986). The repose angle was measured according to the following formula,

$$
\omega=\tan ^{-2} \mathrm{~h} / 0.5 \mathrm{x}
$$

Where:

$\mathrm{h}=$ height of the cone formed by the seeds,

$\mathrm{x}=$ diameter of the base of the cone.

\section{Real and Bulk densities:}

Individual seeds were taken at randomly to determine the real density and quantities of seeds were taken, randomly to determine the bulk density. Real " $\mathrm{P}_{\mathrm{g}}$ " and Bulk " $\mathrm{P}_{\mathrm{b}}$ " densities of seeds were calculated according to the formula:

$$
\mathrm{P}_{\mathrm{g}}=\mathrm{M} / \mathrm{V}
$$

Where:

$$
\mathrm{P}_{\mathrm{g}}=\text { real density of an individual seed, } \mathrm{g} / \mathrm{cm}^{3} \text {; }
$$


$\mathrm{M}=$ mass of an individual seed, $\mathrm{g}$;

$\mathrm{V}=$ volume individual seed, $\mathrm{cm}^{3}$.

$\mathrm{P}_{\mathrm{b}}=\mathrm{Mb} / \mathrm{Vb}$

Where:

$\mathrm{P}_{\mathrm{b}}=$ bulk density of seeds, $\mathrm{g} / \mathrm{cm}^{3}$;

$\mathrm{Mb}=$ mass of the quantity, $\mathrm{g}$;

$\mathrm{Vb}=$ volume of the quantity.

\section{Terminal velocity:}

The terminal velocity of seeds were measured using the terminal velocity apparatus, according to Awady and El-Sayed (1994). The air flowed upwards in the tube from the bottom to top and the air velocity at which the major fraction of sample remained suspended was recorded by using an anemometer. Ten replicates were undertaken for each sample.

Test procedures for the experimental aeromechanical winnowing unit.

The experiments were carried out to study the effect of the following factors on the cleaning efficiency and losses.

\section{-Factor relating to the suspending velocity:}

The terminal velocity was measured to determine the suspending velocities for clover seeds and their impurities.

- Factor relating to the constructed cleaning machine:

The following factors were tested to show their effect on separation effectiveness:

1- Sieve tilt-angle : Three different sieve tilt-angles were under test: zero, 3, 6 degree.

2 -Air speed: Three different air speeds were under test: 4,6 and $8 \mathrm{~m} / \mathrm{s}$.at fan speed 650, 700 and 750 r.p.m.

3- Sieve oscillation: Three different sieve oscillations were under test : 150, 250, 350 and 550 r.p.m.

4 - Shape of screen holes: Round shape of screen holes was used $(4 \mathrm{~mm}$ diameter).

5 - Moisture content: $10.5 \%$ moisture content was used.

6 - Feed rate: $500 \mathrm{~kg} / \mathrm{h}$ feed rate was used.

\section{-Purity:}

Purity; seeds ratio after removing the impurities (mass basis). 
PROCESS ENGINEERING

Purity $\%=($ mass of clean sample /sample of mass before cleaning)x100(10) -Total losses;

Total losses $=($ Seed lost behind the machine $/$ Seed output $) \times 100----$ (11)

\section{RESULTS AND DISCUSSION}

\section{1-The main dimensions:}

Table (1) shows the mean dimensions of clover seeds length " L", width " W" and thickness of the tested seeds of the three clover varieties, and the coefficient of variation for the measurements. Figs (2) represent frequency distribution for $\mathrm{L}, \mathrm{W}$, and $\mathrm{T}$. The distribution of the measured quantities for each variety shows a trend to the normal distribution. The frequency of each variety lies within a narrow range, which is favorable for screen pores. The data listed in table (1) and the distributions represented by Figs. (2) are useful in the determination of the dimensions of the holes of the screens and the dimension of the working elements of the cleaning machines suitable for use in Egypt. A cleaning sieve of a hole diameter of $4 \mathrm{~mm}$ is suitable to be used to clean the seeds from dust and foreign materials, the set of sieves ranged from $4-6 \mathrm{~mm}$ could be suitable to graduate the seeds to different sizes.

Also, volume, geometric diameter, arithmetic diameter, percentage of sphericity, bulk density, true density, transverse surface area, flat surface area, mass of 1000 seeds and moisture content $\%$ for clover seeds are shown in table (1).

\section{Clover angle of friction:}

Friction angle for the investigation clover on the metal surface was measured is values are in table2. It was 31,31 and $32^{\circ}$ ( variety clover).

\section{Clover angle of repose:}

Repose angle of seeds clover was determined is values are in table 2. It was 34, 34 and 35 degree ( variety clover).

\section{Terminal velocity of seeds clover and impurities:}

Terminal velocity of both seeds clover and their impurities were determined by using the floating apparatus and listed in table 2. The maximum terminal velocity for impurities is $5.5 \mathrm{~m} / \mathrm{s}$. and the maximum terminal velocity for seeds clover (variety AL-Meqawei - AL-KhadrawiAL-Seadi) was $15 \mathrm{~m} / \mathrm{s}, 15 \mathrm{~m} / \mathrm{s}$ and $16 \mathrm{~m} / \mathrm{s}$. So that the recommendation of these case is using air velocity of $6 \mathrm{~m} / \mathrm{s}$ for separating seeds clover 
Table (1) : some properties of clover seeds

\begin{tabular}{|c|c|c|c|c|c|c|}
\hline variety & \multicolumn{2}{|c|}{ AL-Khadrawi } & \multicolumn{2}{|c|}{ AL-Khadrawi } & \multicolumn{2}{|c|}{ AL-Seadi } \\
\hline Seed parameter & mean & C.V \% & mean & C.V \% & mean & C.V \% \\
\hline Length (L),mm & 2.40 & 6.5 & 2.45 & 6.7 & 3.30 & 7.5 \\
\hline Width (W),mm & 2.10 & 5.3 & 2.12 & 4.3 & 2.10 & 5.6 \\
\hline Moisture content(Mc) \% & 9.50 & & 10.0 & & 10.1 & \\
\hline $\begin{array}{l}\text { Mass of } 1000 \text { seeds } \\
(\mathrm{M}), \mathrm{g}\end{array}$ & 10.20 & 7.8 & 11.20 & 7.3 & 11.25 & 8.8 \\
\hline Volume (V), $\mathrm{mm}^{3}$ & 4.55 & 10. & 4.65 & 10. & 5.36 & 10. \\
\hline $\begin{array}{l}\text { Percent of sphericity } \\
\text { (S), } \%\end{array}$ & 85 & 12 & 86 & 11 & 63 & 15 \\
\hline $\begin{array}{l}\text { Geometric diameter }\left(\mathrm{D}_{\mathrm{g}}\right) \text {, } \\
\mathrm{mm}\end{array}$ & 2.19 & 4.2 & 2.23 & 4.5 & 2.44 & 4.4 \\
\hline $\begin{array}{l}\text { Arithmetic diameter }\left(\mathrm{D}_{\mathrm{a}}\right), \\
\mathrm{mm}\end{array}$ & 2.2 & 7.3 & 2.23 & 5.3 & 2.5 & 3.3 \\
\hline $\begin{array}{l}\text { Transverse surface area } \\
\left(A_{t}\right), m^{2}\end{array}$ & 3.90 & 8.3 & 3.52 & 8.3 & 3.46 & 9.3 \\
\hline $\begin{array}{l}\text { Flat surface } \\
\operatorname{area}\left(A_{f}\right), m^{2}\end{array}$ & 3.95 & 12 & 4.07 & 11 & 5.44 & 12 \\
\hline $\begin{array}{l}\text { Balk density (Bd), } \\
\mathrm{Kg} / \mathrm{m}^{3}\end{array}$ & 0.4 & & 0.45 & & 0.49 & \\
\hline
\end{tabular}

2 - Mechanical properties of clover ( variety AL-Meqawei - ALKhadrawi- AL-Seadi )

Friction angle, coefficient of friction, angle of repose, and terminal velocity are shown in table (2).

Table (2): Mechanical properties of clover

\begin{tabular}{|c|c|c|c|}
\hline \multirow{2}{*}{ Mechanical properties } & \multicolumn{3}{|c|}{ Variety clover } \\
\cline { 2 - 4 } & AL-Meqawei & AL-Khadrawi & AL-Seadi \\
\hline $\begin{array}{c}\text { Friction angle for metal } \\
\text { surface, degree }(\theta)\end{array}$ & $\mathbf{3 1}$ & $\mathbf{3 1}$ & $\mathbf{3 2}$ \\
\hline $\begin{array}{c}\text { Angle of repose, } \\
\text { degree }(\omega)\end{array}$ & $\mathbf{3 4}$ & $\mathbf{3 4}$ & $\mathbf{3 5}$ \\
\hline $\begin{array}{c}\text { Terminal velocity of } \\
\text { seeds clover( }\left(\mathrm{V}_{\mathrm{t} 1}\right), \mathrm{m} / \mathrm{s}\end{array}$ & $\mathbf{1 5}$ & $\mathbf{1 5}$ & $\mathbf{1 6}$ \\
\hline $\begin{array}{c}\text { Terminal velocity of } \\
\text { impurities, } \mathrm{m} / \mathrm{s}\left(\mathrm{V}_{\mathrm{t} 2}\right)\end{array}$ & $\mathbf{5 . 5}$ & $\mathbf{5 . 5}$ & $\mathbf{5 . 5}$ \\
\hline
\end{tabular}




\section{3 - The results of cleaning machine:}

\section{Selecting technical parameters of portable seeds clover cleaner:}

By studying the physical and mechanical properties of clover, it is easy to determine the type and the dimensions of the screen holes and the working elements of seed cleaning and separating machine. The frequency curve for length, width, and thickness for clover crop used in investigation in fig. 2 and the results in table 1 . It is clear that the separation can be achieve on the basis of length, using a screen aperture of $4 \mathrm{~mm}$. diameter, where about $99 \%$ of seeds clover is recovered associated with $0.01 \%$ of total losses.

On the basis of terminal velocity characteristic, using an air velocity of 6 $.00 \mathrm{~m} / \mathrm{s}$. impurities are rejected without any seeds clover losses.

\section{Effect of air speed on purity and total losses.}

By increasing air speed, the purity increased at different sieve tilt-angles, and sieve oscillations (screen speed) at moisture content of $10.5 \%$, shape of screen holes round and feed rate of $500 \mathrm{Kg} / \mathrm{h}$ as shows in fig.3. For instance, at sieve tilt-angle of 3 degree, and sieve oscillation 350 r.p.m, purity increased from 97 to $99 \%$ at air speed increasing from 4 to $6 \mathrm{~m} / \mathrm{s}$. ( fan speed from 650 to 750 r.pm). Increased purity is due to increase in air quantity capable to suck more seeds clover and impurities.

The total losses decreased by increasing air speed at different sieve tiltangles, and sieve oscillations at moisture content of $10.5 \%$, shape of screen holes round and feed rate of $500 \mathrm{~kg} / \mathrm{h}$ as shown in fig.4. For instance, at sieve tilt-angle of 3 degree, and sieve oscillation 350 r.p.m, total losses decreased from 0.31 to $0.01 \%$ at air speed increasing from 4 to $6 \mathrm{~m} / \mathrm{s}$. ( fan speed from 650 to 750 r.p.m). Decreased losses are due to increase of air quantity pushing more seeds.

Above mentioned results suggested that the highest purity and least losses were at air speed $6 \mathrm{~m} / \mathrm{s}$. (fan speed $700 \mathrm{rpm}$ ).

\section{Effect of sieve tilt-angle on purity and total losses.}

The purity was found to increase as sieve tilt-angle increased at different air speeds, and sieve oscillations at moisture content of $10.5 \%$, shape of screen holes round and feed rate of $500 \mathrm{~kg} / \mathrm{h}$., as shown in fig. 3. For instance, at air speed of $6 \mathrm{~m} / \mathrm{s}$, and sieve oscillation 350 r.p.m., purity 


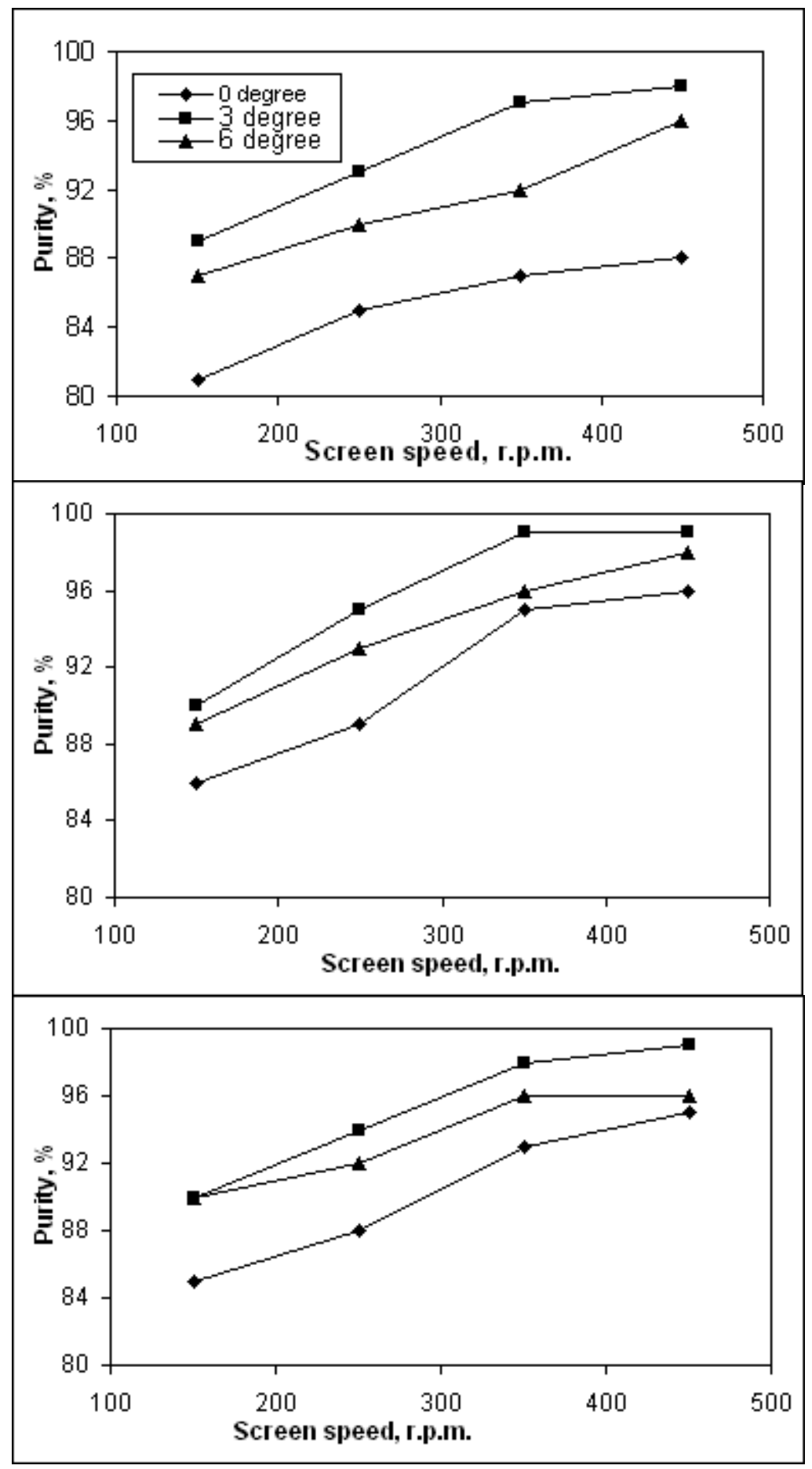

Fig. (3): Effect of screen speed on purity at different sieve tilt angles, and air speeds and round screen hole $4 \mathrm{~mm}$. 

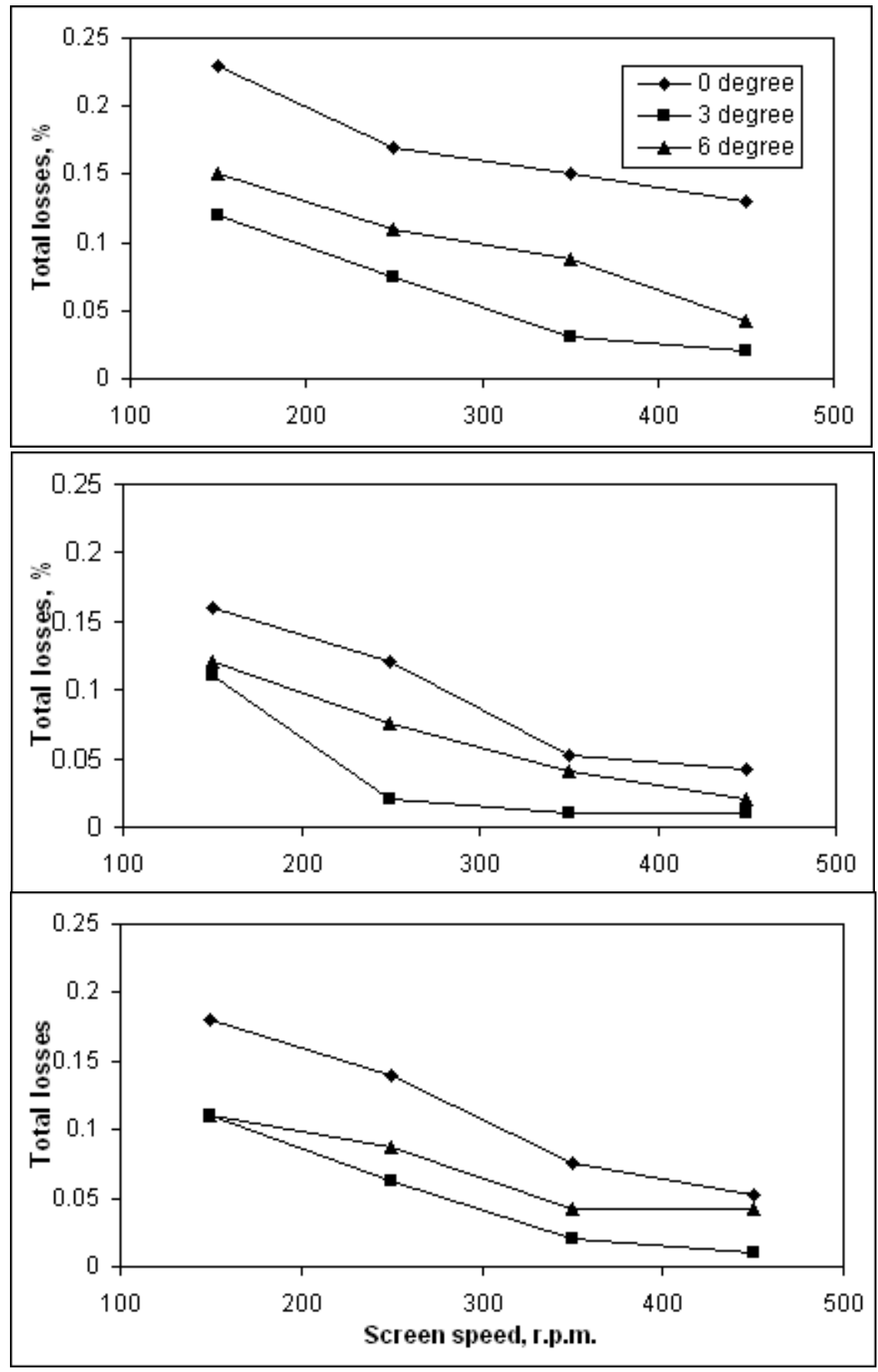

Fig. (4): Effect of screen speed on total losses at different sieve tilt angles, and air speeds and round screen hole $4 \mathrm{~mm}$. 
increased from 95 to $99 \%$ at sieve tilt-angle increased from zero to 3 degree. Increase of purity is due to increased movement of threshed material fast on the sieve giving less chance for straw and impurities to pass through the grain spout by increasing sieve tilt angle.

By increasing sieve tilt angle, the total losses decreased at different air speeds, and sieve oscillations at moisture content of $10.5 \%$, shape of screen holes round and feed rate of $500 \mathrm{~kg} / \mathrm{h}$. as shown in fig. 4 for instance, at air speed of $6 \mathrm{~m} / \mathrm{s}$ and sieve oscillation 350 r.p.m., total losses decreased from 0.15 to $0.01 \%$ at sieve tilt angle increased from zero to 3 degree. Loss refers to increasing jerking movement of threshed material at high sieve tilt angle causing losses behind sieve.

Above mentioned results suggested that highest purity and least losses were at sieve tilt angle 3 degree.

\section{Effect of sieve oscillation on purity and total losses.}

When sieve oscillation increased, the purity increased at different air speeds, and sieve tilt angle, at moisture content of $10.5 \%$ shape of screen holes round and feed rate of $500 \mathrm{~kg} / \mathrm{h}$. as shown in fig 3 . For instance, at air speed of $6 \mathrm{~m} / \mathrm{s}$ and sieve tilt angle 3 degree, purity increased from 9 . to $99 \%$ at sieve oscillation increased from 150 to 350 r.p.m.

By increasing sieve oscillation, the total losses decreased, at different air speeds, and sieve tilt angles, at moisture content of $10.5 \%$, shape of screen holes round and feed rate of of $500 \mathrm{~kg} / \mathrm{h}$. as shown in fig.4. for instance at air speed of $6 \mathrm{~m} / \mathrm{s}$ and sieve tilt angle 3 degree, total losses decreased from 0.11 to 0.01 as sieve oscillation increased from 150 to 350 r.p.m.

The above mentioned results suggested that the highest purity and least losses were at sieve oscillation 350 r.p.m.

\section{REFERENCES}

Ahmed, S.F., (1988). Effect of control and management on the performance of grain sieve cleaners, Com. Dev. Res. 21(254): 93106.

Ahmed, S.f.; M.M. Abou El-Kheir and I.M. Abd EI-Tawwab 1993, Development of an apparatus suitable for separating wheat products from stationary threshers, Misr. J. Ag. Eng., 10 (1): 369-382. 
Arora, S. (1991). Physical and aerodynamic properties of rough rice (Oryza sativa) . Indian J. Ag. Eng., 1, (1): !2-22.

ASAE. (1994) Standards engineering practices data. ISBN 0-929355-50.4 Library of congress.By the ASAE : 469.

Awady, M.N., and A. S. Sayed, (1994), Separation of peanut seeds by air stream, MJAE., 11 (1): 137-147.

Ebaid, M. T.; A.A . Abd El-Rhman; and T. Fouda (2003) " Determine the terminal velocity for some grain crop and their impurities, Misr. J. Ag. Eng., 20 (3): 854- 855.

EL-Raie, A.E.S. (1987), Properties of shelled corn related to mechanical separation. Misr J. Ag. Eng. 4(1): 36-51.

EL-Raie; A.E.s.;N.A.Hendawy and A.Z. Taib, (1996), Study of physical and engineering properties for some agricultural products.Misr.J . Ag. Eng., 13(1): 211-226.

Gomea, G.R. (1992), A study of some factors affecting grain cleaning efficiency. MSc the Ag. Eng. Dept. faculty of Agriculture. ELMonofia University: $66-78$.

Harmond, J.E., N.R. Brandenbug and L.A. Jensen. (1965), Physical properties of seeds. Trans. ASAE, 8(1): 30-32.

Hindey, F.L. and M.A.EL-Tawil (1998), A prototype of continuous flow fluidized bed machine for separating and cleaning wheat grain. Misr. J. Ag. Eng., 15 (2).

IRRI (1978), Operators manual, portable grain cleaner. Eng. Dep., IRRI, Los Banos, Laguna, Philippines. Issue 1:1-15.

Islam, Md. N.; U.A.Kamal; and A.K.M. Moniruzzaman (1980), Desing and construction of manually operated seed cleaning and grading machine," A.M.A., XI (1) : 56 -58.

Khan, A. U., B. Duff, D. O.Kuefther, and J.A Mc Mennamy, (1975), Small oscillating grain cleaner, Rice Machinery Dev. And Mech. Res., Semi-an. Prog. Rep. No. 21,IRRI, Manila, Philippines: 14-15.

Mohsenin, N. N., (1986) Physical properties of plant and animal materials , Gordon and Breach Sc. Pub., N.Y.: 734. 
Nimkar, P.M: and P. K .Chattopadyay, (2001), Some physical properties of green gram, J. of Ag. Eng. Res., 2001, 80, N8(2):183189, 17 Pearson, T. C.; D. C. Slaughter; and H. E. Studer, (1994) Physical properties of pistachio nuts , Trans. of the ASAE., 37 (3) : 913-918.

Soliman, N. S. (1994) Effect of moisture content on angle of repose of paddy rice and its products. Misr J. Ag. Eng. 11(1): 163-173.

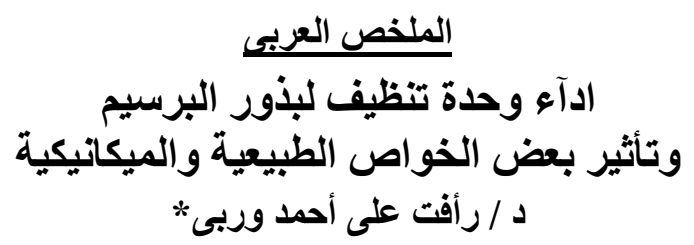

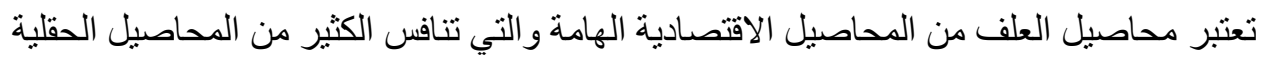

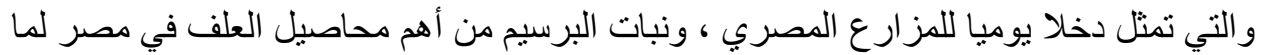

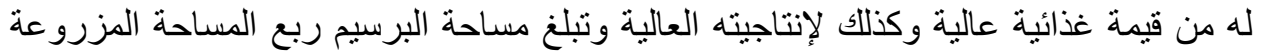

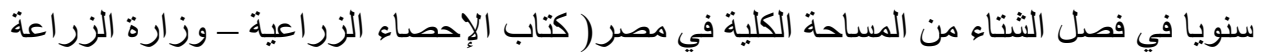

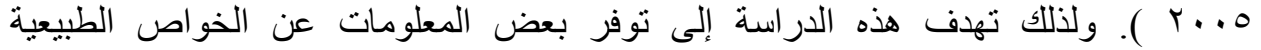

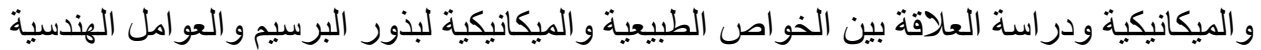

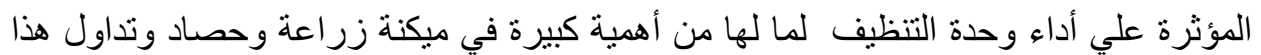

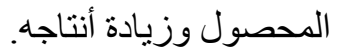
وتمت الدراسة على ثلاثة أصناف من بذور نبات البرسيم الأكثر انتشارا ( المسقاوى،

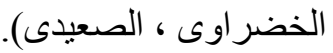

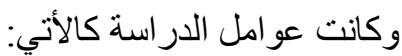

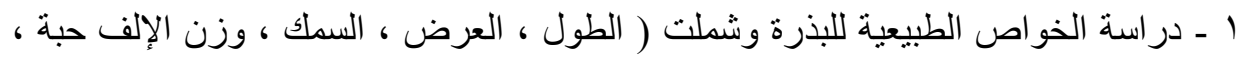

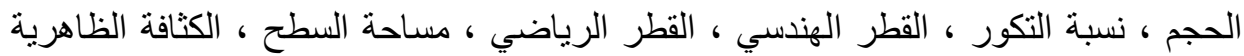

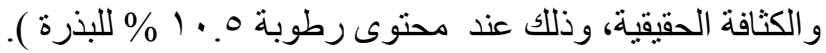

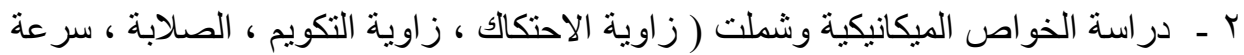

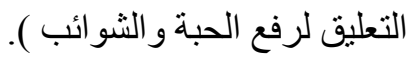
وكذلك تمت دراسة بعض المتغيرات المرتبطة بوحدة التنظيف مثل أقطار فتحات الغربال

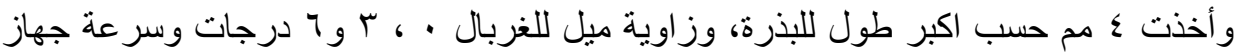

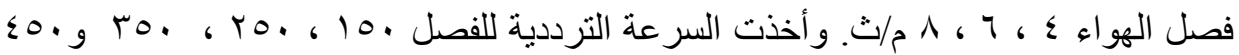

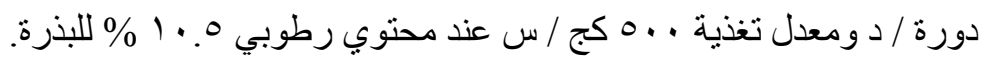
وكان منوسط القيم لبعض الخو اص كالتالي:

*مدرس- قسم الهندسة الزراعيةـ كلية الزراعة ـ جامعة الأزهر- القاهرة. 


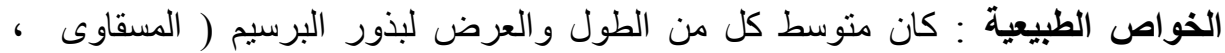

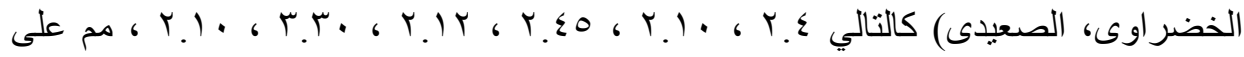

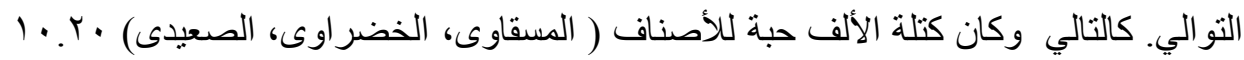

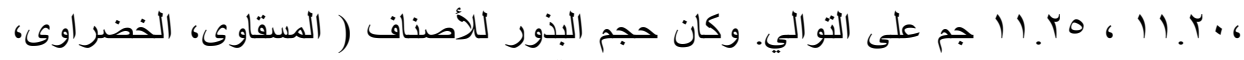

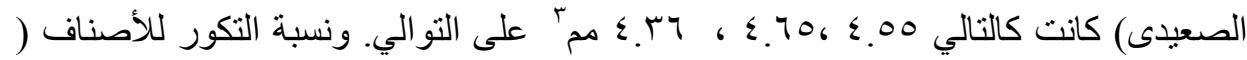

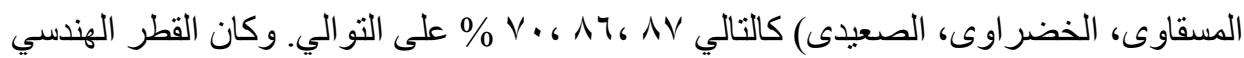

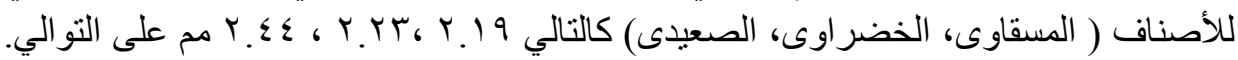

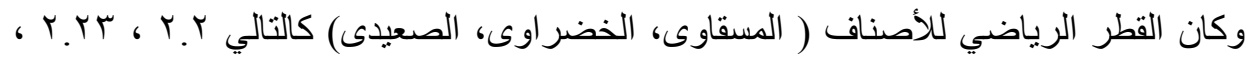

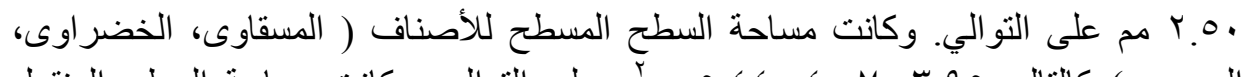

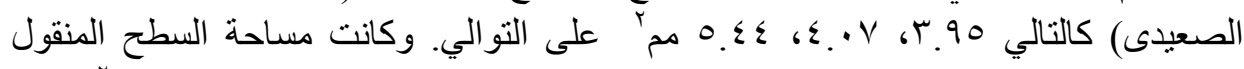

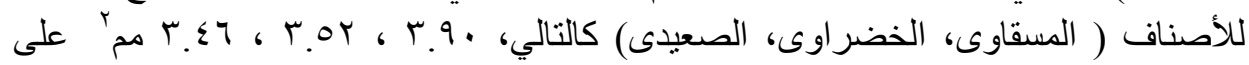

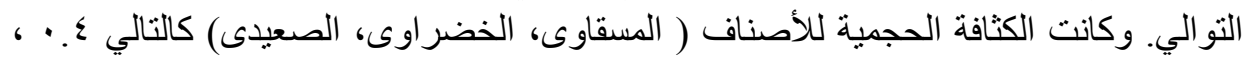

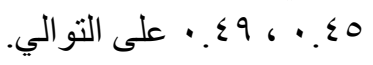

الخواص الميكاتيكية : وجد أن زاوية الاحتكاك للأصناف ( المسقاوى، الخضراوى،

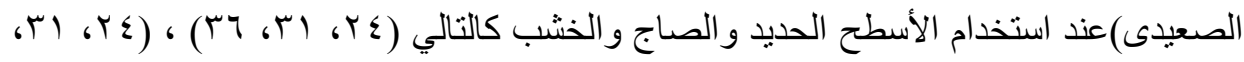

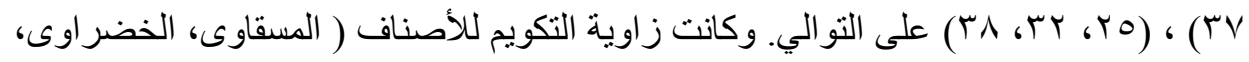

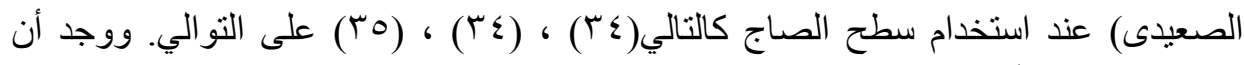

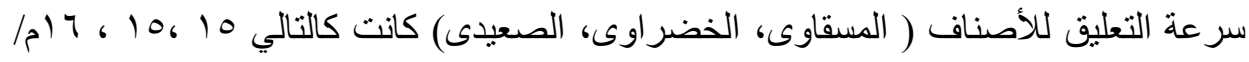

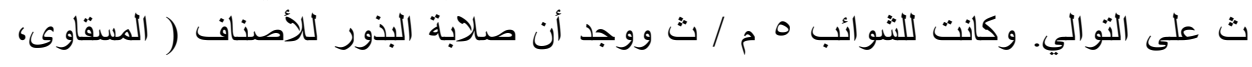

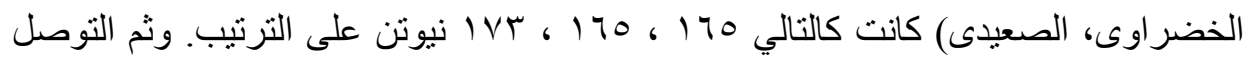
إلى علاقة تربط بين الأبعاد الأساسية والحجم ومساحة السطح حيث يمكن التنبؤ بحجم البذرة

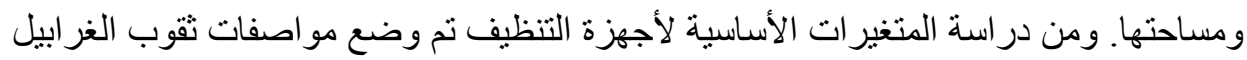

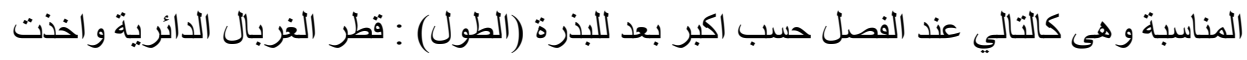

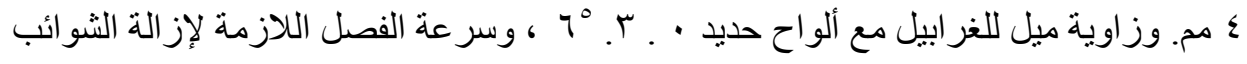
.

وللحصول علي اعلي نسبة نظافة واقل شوائب لبذور البرسيم عموما وفي ظل ظروف البحث

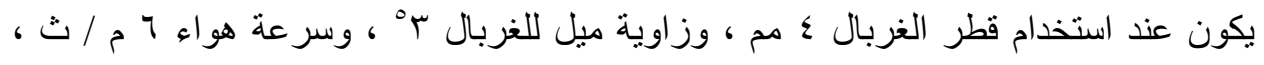

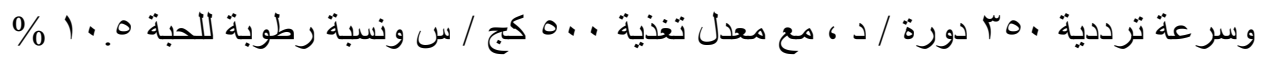

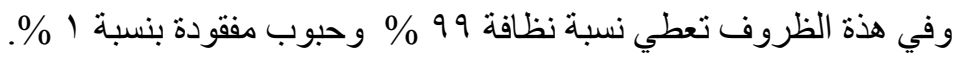

